\title{
Genetic Variability, Heritability and Genetic Advance in Durum Wheat (Triticum durum Desf.)
}

\author{
H.K. Rathwa*, A.G. Pansuriya, J.B. Patel and R.K. Jalu
}

Department of Genetics and Plant Breeding, College of Agriculture, Junagadh Agricultural University, Junagadh - 362 001, Gujarat, India

*Corresponding author

\section{A B S T R A C T}

\begin{tabular}{|c|}
\hline Keywords \\
\hline $\begin{array}{l}\text { Durum wheat, } \\
\text { GCV, PCV, } \\
\text { Variability, Genetic } \\
\text { advance, } \\
\text { Heritability }\end{array}$ \\
\hline Article Info \\
\hline $\begin{array}{l}\text { Accepted: } \\
10 \text { December } 2017 \\
\text { Available Online: } \\
10 \text { January } 2018\end{array}$ \\
\hline
\end{tabular}

The Experiment was carried out to assess genetic variability with respect to grain yield and its components for heat tolerance in durum wheat. The values of phenotypic coefficient of variation in both sowing conditions were slightly higher than that of genotypic coefficient of variation for all the traits studied, indicating less effect of environment on the expression of characters studied. The genetic advance at $5 \%$ selection intensity $(\mathrm{k}=2.06)$ was found high under $\mathrm{D}_{0}$ condition for number of grains per main spike, harvest index and biological yield per plant. Under $\mathrm{D}_{0}$ condition moderate genetic advance was observed for days to $50 \%$ flowering, plant height, grain filling period, days to maturity, chlorophyll content at anthesis $\left(\mathrm{CHL}_{\mathrm{a}}\right)$ and grain yield per plant, while under $\mathrm{D}_{1}$ condition for number of grains per main spike and harvest index. High heritability coupled with high genetic advance expressed as percentage of mean were observed for all characters except under $\mathrm{D}_{0}$ condition for days to maturity, plant height and length of main spike, while under $\mathrm{D}_{1}$ condition for days to maturity, grain filling period, length of main spike and 100-grain weight, which may be attributed to the preponderance of additive gene action and possessed high selective value and thus, selection pressure could profitably be applied on these characters for their rationale improvement.

\section{Introduction}

Wheat belongs to the genus Triticum of the family Poaceae and its origin is believed to be the Middle East Region of Asia (Lupton, 1987). Three species of wheat viz., Triticum aestivum L. (bread wheat), Triticum durum Desf. (Macaroni wheat) and Triticum dicoccum Schulb. (Emmer wheat) are grown commercially in India, covering 86, 12, and 2 per cent of the total area under wheat, respectively (Ukani et al., 2015).
Wheat is one of the most important and widely cultivated crops in the world, used mainly for human consumption and support nearly 35\% of the world population (Mohammadi-joo et $a l ., 2015)$ and providing 20 per cent of the total food calories. Wheat is the second most important staple food next to rice. It has been described as the 'King of cereals' because of the acreage it occupies, high productivity and the prominent position it holds in the international food grain trade. It is known for its remarkable adoption to a wide range of 
environments and its role in the world economy.

The most durum wheat is grown in the Mediterranean countries, the former Soviet Union, North America, and Argentina. U.S. durum production is primarily in North Dakota. However, the largest producer of durum is Canada where it is the third most prominent crop behind red spring wheat and canola, the primary region for durum is in the southern quarter of Saskatchewan. World production of durum wheat ranges from 30-35 million tonnes. More than 80 per cent of the total product is consumed in the country of production, with only Canada, USA and Argentina being mainly exporters. Durum wheat accounts for only 4 per cent of the total world production. Nearly 10-12 million tonnes of durum, valued around US \$2600 million is traded annually (Singh et al., 2011).

\section{Materials and Methods}

The experimental material consisted of 50 diverse genotypes of durum wheat (Triticum durum Desf.) under timely and late sowing condition for 50 genotypes of durum wheat in a Randomized Block Design with three replications during rabi2015-2016 at Wheat Research Station, Junagadh Agricultural University, Junagadh. Each entry was accommodated in a single row of $2.5 \mathrm{~m}$ length with a spacing of $22.5 \mathrm{~cm}$ between two rows. The recommended agronomical practices and plant protection measures were followed for the successful raising of the crop. Five competitive plants per genotype in each replication were randomly selected for recording observations on different characters viz., Days to $50 \%$ flowering, Days to maturity, Grain filling period (Days), Plant height $(\mathrm{cm})$, Number of productive tillers per plant, Length of main spike $(\mathrm{cm})$, Number of grains per main spike, Grain weight per main spike (g), Grain yield per plant (g), Biological yield per plant (g), Harvest index (HI) (\%), 100-grain weight (g), Chlorophyll content at anthesis (SPAD unit), Chlorophyll content at 21 days after anthesis (SPAD unit), Canopy temperature depression at vegetative stage $\left({ }^{\circ} \mathrm{C}\right)$ and Canopy temperature depression at grain filling stage $\left({ }^{\circ} \mathrm{C}\right.$ ) (except days to $50 \%$ flowering, grain filling period and days to maturity) and their averages were used in the statistical analysis. The analysis of variance for RBD was carried out by linear model suggested by Panse and Sukhatme (1985).

The genotypic coefficient of variation, which measures the magnitude of genetic variation present in a particular character, was estimated as per the formula suggested by Burton and DeVane (1953). The phenotypic coefficient of variation, which measures the magnitude of phenotypic variation present in a particular character, was estimated as per the formula suggested by Burton and DeVane (1953).The expected genetic advance under selection (GA) and heritability were estimated as per the formula described by Allard (1960). The genetic advance expressed as percentage of mean was computed by method suggested by Johnson et al., (1955).

\section{Results and Discussion}

The better index for measuring the genetic variation is genetic co-efficient of variation (GCV) as described by Burton and De Vane (1953) for comparing the genetic variability present in different traits. The estimates of genotypic and phenotypic coefficient of variability in both the sowing conditions indicated that the values of phenotypic coefficient of variation were slightly higher than that of genotypic coefficient of variation for all the traits studied, indicating less effect of environment on the expression of characters studied. Similar results have also been reported by Malav (2015) and Wolde et al., (2016). 
The high values of GCV were observed under timely sowing condition $\left(\mathrm{D}_{0}\right)$ for number of productive tillers per plant followed by canopy temperature depression at grain filling stage, number of grains per main spike, grain yield per plant, canopy temperature depression at vegetative stage, harvest index, biological yield per plant, grain weight per main spike and 100-grain weight. The high values of GCV were observed under late sowing condition $\left(\mathrm{D}_{1}\right)$ for canopy temperature depression at grain filling stage followed by number of productive tillers per plant, canopy temperature depression at vegetative stage, number of grains per main spike, grain yield per plant, biological yield per plant, grain weight per main spike, harvest index and 100grain weight.

The moderate values of GCV were observed under timely sowing condition $\left(\mathrm{D}_{0}\right)$ for length of main spike, grain filling period, chlorophyll content at anthesis, chlorophyll content at 21 days after anthesis, days to $50 \%$ flowering and plant height. The moderate values of GCV were observed under late sowing condition $\left(\mathrm{D}_{1}\right)$ for grain filling period, days to $50 \%$ flowering, chlorophyll content at 21 days after anthesis, chlorophyll content at anthesis and length of main spike. Plant height remains low in late sowing condition. These findings are in corroboration with those reported by earlier reports by Desheva and Cholakov (2014), Maurya et al., (2014) and Desheva and Kyosev (2015).

The low value of GCV was observed under timely sowing condition $\left(\mathrm{D}_{0}\right)$ for days to maturity. The low value of GCV was observed under late sowing condition $\left(D_{1}\right)$ for plant height and days to maturity. The finding of these characters is supported by earlier reports of Abinasa et al., (2011) and Baranwal et al., (2012). High phenotypic coefficient of variation (PCV) was observed under timely sowing condition $\left(\mathrm{D}_{0}\right)$ for grain yield per plant in the present study followed by canopy temperature depression at grain filling stage, number of productive tillers per plant, number of grains per main spike, canopy temperature depression at vegetative stage, grain yield per plant, harvest index, biological yield per plant, grain weight per main spike, 100-grain weight and length of main spike. Grain filling period, chlorophyll content at anthesis, plant height, chlorophyll content at 21 days after anthesis and days to $50 \%$ flowering exhibited moderate value of PCV, whereas days to maturity noted low values of PCV. High PCV was observed under late sowing condition $\left(D_{1}\right)$ for canopy temperature depression at grain filling stage, number of productive tillers per plant, canopy temperature depression at vegetative stage, number of grains per main spike, grain yield per plant, 100-grain weight, grain weight per main spike, biological yield per plant, harvest index and grain filling period.

Days to 50\% flowering, chlorophyll content at 21 days after anthesis, chlorophyll content at anthesis and length of main spike exhibited moderate value of PCV, whereas plant height and days to maturity noted low values of PCV and also reported by Desheva and Cholakov (2014), Maurya et al., (2014), Said et al., (2014), Desheva and Kyosev (2015) and Wolde et al., (2016).

In the present study, high heritability (broad sense) values were observed under timely sowing condition $\left(\mathrm{D}_{0}\right)$ for biological yield per plant, harvest index, grain yield per plant, number of grains per main spike, number of productive tillers per plant, days to $50 \%$ flowering, chlorophyll content at anthesis, 100-grain weight, days to maturity, grain filling period, grain weight per main spike, chlorophyll content at 21 days after anthesis, canopy temperature depression at grain filling stage and canopy temperature depression at vegetative stage, while moderate estimates for length of main spike and plant height (Table 1 and 2). 
Table.1 Range of variation, mean, phenotypic and genotypic coefficients of variation, heritability (broad Sense), genetic advance and genetic advance expressed as percentage of mean for various characters in 50 genotypes of durum wheat under timely sowing $\left(\mathrm{D}_{0}\right)$

\begin{tabular}{|c|c|c|c|c|c|c|c|}
\hline Character & Range & Mean & $\begin{array}{c}\text { Genotypic } \\
\text { coefficient of } \\
\text { variation }(\%)\end{array}$ & $\begin{array}{l}\text { Phenotypic } \\
\text { coefficient of } \\
\text { variation }(\%)\end{array}$ & $\begin{array}{l}\text { Heritability } \\
\text { (Broad } \\
\text { Sense) } \\
(\%)\end{array}$ & $\begin{array}{l}\text { Genetic } \\
\text { advance }\end{array}$ & $\begin{array}{c}\text { Genetic advance } \\
\text { expressed as } \\
\text { percentage of } \\
\text { mean }\end{array}$ \\
\hline Days to $50 \%$ flowering & 54.33 to 71.67 & 63.51 & 12.87 & 13.17 & 95.50 & 16.45 & 25.90 \\
\hline Days to maturity & 100.12 to 115.53 & 109.27 & 5.92 & 6.39 & 85.90 & 12.36 & 11.31 \\
\hline Grain filling period (Days) & 37.63 to 57.77 & 45.76 & 16.72 & 18.09 & 85.46 & 14.57 & 31.84 \\
\hline Plant height (cm) & 62.33 to 90.89 & 77.36 & 12.50 & 16.16 & 59.87 & 15.42 & 19.93 \\
\hline Number of productive tillers per plant & 3.83 to 12.23 & 7.89 & 50.03 & 50.63 & 97.64 & 8.04 & 101.85 \\
\hline Length of main spike (cm) & 4.33 to 6.71 & 5.54 & 16.87 & 20.20 & 69.71 & 1.61 & 29.01 \\
\hline Number of grains per main spike & 28.33 to 67.00 & 45.14 & 38.79 & 39.13 & 98.25 & 35.76 & 79.20 \\
\hline Grain weight per main spike (g) & 2.20 to 3.96 & 2.90 & 24.68 & 26.94 & 83.92 & 1.35 & 46.57 \\
\hline Grain yield per plant (g) & 9.67 to 20.33 & 14.19 & 34.52 & 34.80 & 98.40 & 10.01 & 70.54 \\
\hline Biological yield per plant (g) & 23.67 to 51.00 & 35.61 & 28.43 & 28.48 & 99.62 & 20.81 & 58.45 \\
\hline Harvest index (HI) (\%) & 25.61 to 59.99 & 40.23 & 31.19 & 31.30 & 99.30 & 25.76 & 64.03 \\
\hline 100-grain weight (g) & 3.17 to 5.39 & 4.31 & 22.54 & 23.30 & 93.64 & 1.94 & 44.94 \\
\hline & & & & & & \multicolumn{2}{|r|}{ Conti... } \\
\hline Character & Range & Mean & $\begin{array}{c}\text { Genotypic } \\
\text { coefficient of } \\
\text { variation }(\%)\end{array}$ & $\begin{array}{l}\text { Phenotypic } \\
\text { coefficient of } \\
\text { variation }(\%)\end{array}$ & $\begin{array}{c}\text { Heritability } \\
\text { (Broad } \\
\text { Sense) } \\
(\%)\end{array}$ & $\begin{array}{l}\text { Genetic } \\
\text { advance }\end{array}$ & $\begin{array}{c}\text { Genetic advance } \\
\text { expressed as } \\
\text { percentage of } \\
\text { mean }\end{array}$ \\
\hline $\begin{array}{l}\text { Chlorophyll content at } \\
\text { anthesis(SPAD unit) }\end{array}$ & 25.94 to 40.90 & 33.74 & 16.50 & 16.91 & 95.21 & 11.19 & 33.16 \\
\hline $\begin{array}{l}\text { Chlorophyll content at } 21 \text { days after } \\
\text { anthesis(SPAD unit) }\end{array}$ & 27.88 to 42.40 & 35.00 & 13.64 & 15.11 & 81.49 & 8.88 & 25.36 \\
\hline $\begin{array}{l}\text { Canopy temperature depression at } \\
\text { vegetative stage }\left({ }^{\circ} \mathrm{C}\right)\end{array}$ & 2.04 to 5.53 & 3.93 & 31.55 & 35.33 & 79.75 & 2.28 & 58.03 \\
\hline $\begin{array}{l}\text { Canopy temperature depression at } \\
\text { grain filling stage }\left({ }^{\circ} \mathrm{C}\right)\end{array}$ & 0.90 to 3.90 & 2.52 & 45.80 & 50.84 & 81.16 & 2.14 & 85.00 \\
\hline
\end{tabular}


Table.2 Range of variation, mean, phenotypic and genotypic coefficients of variation, heritability (broad Sense), genetic advance and genetic advance expressed as percentage of mean for various characters in 50 genotypes of durum wheat under late sowing $\left(\mathrm{D}_{1}\right)$

\begin{tabular}{|c|c|c|c|c|c|c|c|}
\hline Character & Range & Mean & $\begin{array}{c}\text { Genotypic } \\
\text { coefficient of } \\
\text { variation }(\%)\end{array}$ & $\begin{array}{l}\text { Phenotypic } \\
\text { coefficient of } \\
\text { variation }(\%)\end{array}$ & $\begin{array}{l}\text { Heritability } \\
\text { (Broad } \\
\text { Sense) } \\
(\%)\end{array}$ & $\begin{array}{l}\text { Genetic } \\
\text { advance }\end{array}$ & $\begin{array}{c}\text { Genetic advance } \\
\text { expressed as } \\
\text { percentage of } \\
\text { mean }\end{array}$ \\
\hline Days to $50 \%$ flowering & 45.14 to 65.1 & 55.52 & 17.72 & 18.05 & 96.29 & 19.89 & 35.81 \\
\hline Days to maturity & 87.18 to 108.17 & 98.30 & 6.99 & 8.77 & 63.63 & 11.30 & 11.49 \\
\hline Grain filling period (Days) & 34.27 to 57.33 & 42.78 & 18.32 & 22.37 & 67.07 & 13.22 & 30.91 \\
\hline Plant height (cm) & 55.47 to 70.76 & 64.31 & 9.91 & 9.96 & 99.05 & 13.06 & 20.31 \\
\hline Number of productive tillers per plant & 2.44 to 10.91 & 5.99 & 53.05 & 54.03 & 96.40 & 6.43 & 107.30 \\
\hline Length of main spike (cm) & 5.14 to 7.64 & 6.28 & 13.64 & 16.79 & 66.00 & 1.43 & 22.82 \\
\hline Number of grains per main spike & 25.00 to 64.00 & 43.45 & 41.26 & 41.29 & 99.88 & 36.92 & 84.95 \\
\hline Grain weight per main spike (g) & 2.05 to 3.7 & 2.71 & 25.47 & 26.53 & 92.11 & 1.36 & 50.35 \\
\hline Grain yield per plant (g) & 6.87 to 15.63 & 11.14 & 36.33 & 36.87 & 97.07 & 8.22 & 73.73 \\
\hline Biological yield per plant (g) & 20.00 to 38.33 & 27.39 & 26.01 & 26.13 & 99.02 & 14.60 & 53.31 \\
\hline Harvest index (HI) (\%) & 25.78 to 48.82 & 40.64 & 25.31 & 25.73 & 96.78 & 20.84 & 51.29 \\
\hline 100-grain weight (g) & 2.50 to 5.50 & 4.02 & 24.66 & 30.83 & 63.95 & 1.63 & 40.62 \\
\hline & & & & & & \multicolumn{2}{|r|}{ Conti... } \\
\hline Character & Range & Mean & $\begin{array}{c}\text { Genotypic } \\
\text { coefficient of } \\
\text { variation }(\%)\end{array}$ & $\begin{array}{l}\text { Phenotypic } \\
\text { coefficient of } \\
\text { variation }(\%)\end{array}$ & $\begin{array}{c}\text { Heritability } \\
\text { (Broad } \\
\text { Sense) } \\
(\%)\end{array}$ & $\begin{array}{l}\text { Genetic } \\
\text { advance }\end{array}$ & $\begin{array}{c}\text { Genetic advance } \\
\text { expressed as } \\
\text { percentage of } \\
\text { mean }\end{array}$ \\
\hline $\begin{array}{l}\text { Chlorophyll content at anthesis } \\
\text { (SPAD unit) }\end{array}$ & 29.28 to 44.93 & 37.28 & 16.81 & 16.90 & 98.95 & 12.84 & 34.45 \\
\hline $\begin{array}{l}\text { Chlorophyll content at } 21 \text { days after } \\
\text { anthesis (SPAD unit) }\end{array}$ & 24.91 to 39.79 & 32.70 & 17.04 & 17.15 & 98.68 & 11.40 & 34.87 \\
\hline $\begin{array}{l}\text { Canopy temperature depression at } \\
\text { vegetative stage }\left({ }^{\circ} \mathrm{C}\right)\end{array}$ & -0.83 to 5.17 & 3.51 & 44.96 & 48.35 & 86.46 & 3.02 & 86.13 \\
\hline $\begin{array}{l}\text { Canopy temperature depression at } \\
\text { grain filling stage }\left({ }^{\circ} \mathrm{C}\right)\end{array}$ & 0.57 to 4.74 & 2.41 & 71.31 & 75.87 & 88.33 & 3.33 & 138.06 \\
\hline
\end{tabular}


High heritability (broad sense) values were observed under late sowing condition $\left(D_{1}\right)$ for number of grains per main spike, plant height, biological yield per plant, chlorophyll content at anthesis, chlorophyll content at 21 days after anthesis, grain yield per plant, harvest index, number of productive tillers per plant, days to $50 \%$ flowering, grain weight per main spike, canopy temperature depression at grain filling stage and canopy temperature depression at vegetative stage, while moderate estimates for grain filling period, length of main spike, 100grain weight and days to maturity. The high heritability values for different traits indicated that heritability may be due to higher contribution of genotypic component in these traits and also reported by Patel and Jain (2002), Abinasa et al., (2011), Mohammadi et al., (2011), Thanna et al., (2011), Said et al., (2014) and Wolde et al., (2016).

The genetic advance under timely sowing condition $\left(\mathrm{D}_{0}\right)$ at $5 \%$ selection intensity $(k=2.06)$ was found high for number of grains per main spike, harvest index and biological yield per plant. In that $\mathrm{D}_{0}$ condition moderate genetic advance was observed for days to $50 \%$ flowering, plant height, grain filling period, days to maturity, chlorophyll content at anthesis and grain yield per plant, while it was low for all the remaining traits studied. The genetic advance under late sowing condition $\left(\mathrm{D}_{1}\right)$ at $5 \%$ selection intensity $(\mathrm{k}=2.06)$ was found high for number of grains per main spike and harvest index. In that $\mathrm{D}_{1}$ condition moderate genetic advance was observed for days to $50 \%$ flowering, biological yield per plant, grain filling period, plant height, chlorophyll content at anthesis, chlorophyll content at 21 days after anthesis and days to maturity, while it was low for all the remaining traits studied including grain yield per plant and also reported by Yadav et al., (2011), Desheva and Cholakov (2014) and Kumar et al., (2014).

The genetic advance expressed as percentage of mean under timely sowing condition $\left(\mathrm{D}_{0}\right)$ was found high for number of productive tillers per plant, canopy temperature depression at grain filling stage, number of grains per main spike, grain yield per plant, harvest index, biological yield per plant, canopy temperature depression at vegetative stage, grain weight per main spike, 100-grain weight, grain filling period, chlorophyll content at anthesis, length of main spike, days to $50 \%$ flowering and chlorophyll content at 21 days after anthesis, while moderate values of genetic advance expressed as percentage of mean was recorded for plant height and days to maturity. The genetic advance expressed as percentage of mean under late sowing condition $\left(\mathrm{D}_{1}\right)$ was found high for canopy temperature depression at grain filling stage, number of productive tillers per plant, canopy temperature depression at vegetative stage, number of grains per main spike, grain yield per plant, biological yield per plant, harvest index, grain weight per main spike, 100grain weight, days to $50 \%$ flowering, chlorophyll content at 21 days after anthesis, chlorophyll content at anthesis, grain filling period, length of main spike and plant height, while moderate values of genetic advance expressed as percentage of mean was recorded for days to maturity and also reported by Singh et al., (2012), Tsegay et al., (2012), Bhushan et al., (2013), Maurya et al., (2014) and Wolde et al., (2016).

In the present study, high heritability coupled with high genetic advance expressed as percentage of mean were observed under timely sowing condition $\left(\mathrm{D}_{0}\right)$ for days to $50 \%$ flowering, grain filling period, number of productive tillers per plant, number of grains per main spike, grain weight per main spike, grain yield per plant, biological yield per plant, harvest index, 100-grain weight, chlorophyll content at anthesis, chlorophyll content at 21 days after anthesis, canopy temperature depression at vegetative stage and canopy temperature depression at grain filling stage, while under late sowing condition $\left(\mathrm{D}_{1}\right)$ for days to $50 \%$ flowering, plant height, number of productive tillers per plant, number of grains per main spike, grain weight per main spike, grain yield per plant, biological yield per plant, harvest index, chlorophyll content at anthesis, 
chlorophyll content at 21 days after anthesis, canopy temperature depression at vegetative stage and canopy temperature depression at grain filling stage, which may be attributed to the preponderance of additive gene action and possessed high selective value and thus, selection pressure could profitably be applied on these characters for their rationale improvement (Panse, 1957). Moderate heritability with moderate genetic advance expressed as percentage of mean was manifested under timely sowing condition $\left(\mathrm{D}_{0}\right)$ by plant height, while under late sowing condition $\left(D_{1}\right)$ by days to maturity, which indicated non - additive type of gene action controlling these characters, hence there is limited scope for improvement of traits through selection.

The values of phenotypic coefficient of variation in both sowing conditions $\left(\mathrm{D}_{0}\right.$ and $\left.\mathrm{D}_{1}\right)$ were slightly higher than that of genotypic coefficient of variation for all the traits studied, indicating less effect of environment on the expression of characters studied. The high values of GCV were observed under timely sowing condition $\left(\mathrm{D}_{0}\right)$ for number of productive tillers per plant, while under late sowing condition $\left(\mathrm{D}_{1}\right)$ for canopy temperature depression at grain filling stage. The high heritability (broad sense) were observed under timely sowing condition $\left(\mathrm{D}_{0}\right)$ for biological yield per plant, while under late sowing condition $\left(D_{1}\right)$ for number of grains per main spike. The genetic advance at 5\% selection intensity $(\mathrm{k}=2.06)$ was found high under timely sowing condition $\left(\mathrm{D}_{0}\right)$ for number of grains per main spike, while under late sowing condition $\left(D_{1}\right)$ for number of grains per main spike. The genetic advance expressed as percentage of mean was found high under timely sowing condition $\left(\mathrm{D}_{0}\right)$ for number of productive tillers per plant, and under late sowing condition $\left(\mathrm{D}_{1}\right)$ for canopy temperature depression at grain filling stage. High heritability coupled with high genetic advance expressed as percentage of mean were observed under both timely as well as late sowing condition $\left(\mathrm{D}_{0}\right)$ for days to $50 \%$ flowering.

\section{References}

Abinasa, M., Ayana, A. and Bultosa, G. 2011. Genetic variability, heritability and trait associations in durum wheat (Triticum turgidum L. var. durum) genotypes. Afr. J. Agric. Res., 6(17): 3972-3979.

Allard, R.W. 1960. Principles of plant breeding. John Willey and Sons. Inc., New York.

Baranwal, D. K., Mishra, V. K., Vishwakarma, M. K., Yadav, P. S. and Arun, B. 2012. Studies on genetic variability, correlation and path analysis for yield and yield contributing traits in wheat ( $T$. aestivum L. emThell). Pl. Arch., 12(2): 99-104.

Bhushan, B., Sonu, Bharti; Ojha, A., Pandey, M., Gourav, S. S., Tyagi, B. S. and Singh, G. 2013. Genetic variability, correlation coefficient and path analysis of some quantitative traits in bread wheat. $J$. Wheat Res., 5(1): 21-26.

Burton, G. M. and DeVane, E. M. 1953. Estimating heritability in tall Fescue from replication clonal material. Agron. J., 45: 478-481.

Desheva, G. and Cholakov, T. 2014. Variability, heritability and genetic progress for some yield components in common winter wheat genotypes (Triticum aestivum L.). Genet. Pl. Physiol., 4(3-4): 191-200.

Desheva, G. and Kyosev, B. 2015. Genetic diversity assessment of common winter wheat (Triticum aestivum L.). Emir. J. Food Agric., 27(3): 283-290.

Johnson, H. W., Robinson, H. F. and Comstock, R. E. 1955. Genotypic and phenotypic correlations in soybeans and their implications in selection. Agron. J., 47: 477-483.

Kumar, N., Markar, S. and Kumar, V. 2014. Studies on heritability and genetic advance estimates in timely sown bread wheat (Triticum aestivum L.). Biosci. Discov., 5(1): 64-69.

Lupton, F. G. H. 1987. History of Wheat Breeding. In: F. G. H. Lupton (ed.), Wheat Breeding: Its Scientific Basis. Chapman and Hall, London, U.K. 
Malav, A. K. 2015. Genetic variability, character association and diversity analysis in bread wheat (Triticum aestivum L.). M. Sc. (Agri.) Thesis (unpublished) submitted to Junagadh Agricultural University, Junagadh.

Maurya, M., Chaurasia, A. K., Kumar, A., Maurya, C. L., Bara, B. M., Kumar, M. and Rai, P. K. 2014. Genetic variability for seed yield and its component characters in wheat (Triticum aestivum L.) under Allahabad agro climatic condition. Int. J. Recent Develop. Engi. Tech., 2(4): 124-126.

Mohammadi, M., Karimizadeh, R., Shefazadeh, M. K. and Sadeghzadeh, B. 2011. Statistical analysis of durum wheat yield under semi-warm dryland condition. Aus. J. Crop Sci., 5(10): 1292-1297.

Mohammadi-joo, S., Mirasi, A., Saeidiaboeshaghi, R. and Amiri, M. 2015. Evaluation of bread wheat (Triticum aestivum L.) genotypes based on resistance indices under field conditions. Int. J. Bio. Sci., 6(2): 331-337.

Panse, V. G. 1957. Genetics of quantitative traits in relation to plant breeding. Indian J. Genet., 17: 318-328.

Panse, V. G. and Sukhatme, P. V. 1985. Statistical methods for agricultural workers. ( ${ }^{\text {rd }}$ Revised eds.) ICAR, New Delhi.

Patel, A. K. and Jain, S. 2002. Studies of genetic variability in wheat under rainfed condition. JNKVV Res. J., 36: 25-28.

Said, S., Khan, S. J., Khan, J., Khan, R. U. and Khan, I. 2014. Genetic variability studies in bread wheat (Triticum aestivum L.) accessions. Pak. J. Agric. Res., 27(1): 1-6.

Singh, A. K., Singh, S. B., Singh, A. P. and
Sharma, A. K. 2012. Genetic variability, character association and path analysis for seed yield and its component characters in wheat (Triticum aestivum L.) under rainfed environment. Indian J. Agric. Res., 46(1): 48-53.

Singh, K., Sharma, S. N. and Sharma, Y. 2011. Effect of high temperature on yield attributing traits in bread wheat. Bangladesh J. Agril. Res., 36(3): 415-426.

Thanna, H. A., Kareem, A. E., Aml, E. A. and El Saidy 2011. Evaluation of yield and grain quality of some bread wheat genotypes under normal irrigation and drought stress conditions in calcareous soils. J. Biol. Sci., 11(2): 156-164.

Tsegaye, D., Dessalegn, T., Dessalegn, Y. and Share, G. 2012. Genetic variability, correlation and path analysis in durum wheat germplasm (Triticum durum Desf.). Agri. Res. \& Rev., 1(4): 107-112.

Ukani, J. D., Patel, J. B., Dabhi, K. H. and Ribadia, K. H. 2015. Development of identification keys on the basis of plant morphological character in wheat. AGRES-Int. e-J., 4(3): 290-300.

Wolde, T., Eticha, F., Alamerew, S., Assefa, E. and Dutamo, D. 2016. Genetic variability, heritability and genetic advance for yield and yield related traits in 68 durum wheat (Triticum durum L.) accessions. Sky J. Agri. Res., 5(3): 042-047.

Yadav, A. K., Mann, R. K., Kumar, S. and Kumar, P. 2011. Variability, heritability and genetic advance for quantitative characters in hexaploid wheat (Triticum aestivum L.). Electronic J. Pl. Breed., 2(3): 405-408.

\section{How to cite this article:}

Rathwa, H.K., A.G. Pansuriya, J.B. Patel and Jalu, R.K. 2018. Genetic Variability, Heritability and Genetic Advance in Durum Wheat (Triticum durum Desf.). Int.J.Curr.Microbiol.App.Sci. 7(01): 1208-1215. doi: https://doi.org/10.20546/ijcmas.2018.701.147 